\title{
QUANTITATIVE AND QUALITATIVE TRAITS OF TRITICUM DICOCCON SCHRANK - CORRELATION ANALYSIS
}

\author{
Lacko-Bartošová Magdaléna', Lacko-Bartošová Lucia ${ }^{2}$ \\ ${ }^{1}$ Department of Sustainable Agriculture and Herbology, Faculty of Agrobiology and Food Resources, \\ Slovak University of Agriculture in Nitra, Slovakia \\ ${ }^{2}$ Department of Applied Informatics and Computing Technology, University of Economics in Bratislava, \\ Slovakia
}

\section{KORELAČNÉ VZŤAHY KVANTITATÍVNYCH A KVALITATÍVNYCH ZNAKOV PŠENICE DVOJZRNOVEJ}

\author{
Lacko-Bartošová Magdaléna, Lacko-Bartošová Lucia \\ Received 25. 6. 2017 \\ Revised 29. 6. 2017 \\ Published 27. 11. 2017
}

In the present study, the correlation analysis of agronomic and qualitative traits of emmer demonstrated negative, medium strong correlation between stem length and protein content, water absorption and sieve fraction under $2.2 \mathrm{~mm}$. Higher quality traits of emmer are associated with longer stem. Productive spikelets coefficient positively correlated with the most of quality traits and therefore can be an indicator of breadmaking potential of emmer. Very important quality trait is protein content with high positive correlation between Zeleny test, wet gluten content, farinograph water absorption and also between beta-carotene. Strong negative correlation between protein content and gluten index indicated difficulties for breeders to select for high protein and its high quality at the same time. The content of zeaxanthin and beta-carotene correlated with grain size, beta-carotene with grain size of 2.2-2.5 mm, zeaxanthin with grain size higher than 2.5 and $2.8 \mathrm{~mm}$. The content of lutein, free and bound phenolics did not correlated with grain size fractions, but medium strong to strong correlations were recorded between all these phytoprotective traits.

Keywords: Triticum dicoccon Schrank; correlation analysis; quantitative; qualitative traits

\section{Úvod}

Pšenica dvojzrnová je považovaná za predchodcu väčšiny pestovaných druhov pšeníc. Patrí medzi tetraploidné druhy, jej kultúrna forma označovaná tiež ako dvojzrnka (Triticum dicoccum Schübl.) alebo (Triticum dicoccon Schrank) patrí medzi najstaršie využívané obilniny. Pestovaná forma dvojzrnky bola najvýznamnejšou plodinou takmer 7000 rokov, nálezy ako divých, tak aj domestikovaných foriem v oblasti Úrodného polmesiaca sa datujú do obdobia 7700 - 7500 rokov pred naším letopočtom (Feldman 2001).V súčasnom období sa sporadicky pestuje v podhorských a horských oblastiach Zakaukazska, Baškyrska, na Balkánskom poloostrove, v Turecku, Iráne,

*Corresponding author: Magdaléna Lacko-Bartošová, Department of Sustainable Agriculture and Herbology, Faculty of Agrobiology and Food Resources, Slovak University of Agriculture in Nitra, Slovakia, $₫$ magdalena.lacko-bartosova@uniag.sk 
Jemene, Indii, Maroku, Etiópii, z európskych štátov hlavne v Taliansku, Španielsku (región Astúria), Rakúsku.

Dvojzrnka bola po tisícročia základnou obilninou aj na území dnešného Slovenska, v severnej časti východného Slovenska a na Krupinskej pahorkatine sa pestovala ešte do 70. rokov 20. storočia (najmä pod ludovým označením tenkel', gengel).

Pôvodný všeobecný názor predpokladal, že jej pestovanie zaniklo najneskôr v období vrcholného stredoveku. Vysievala sa na podhorské, piesočnaté alebo kamenisté pôdy, najčastejšie na lazoch ako jarina. Nepoliehala, netrpela chorobami, znášala nehnojené pôdy a neúrodné polohy. Úrody dvojzrnky sa pohybovali od 2,0 do 2,5 t/ha (Hajnalová a Dreslerová 2010). Napriek pomerne značnému hospodárskemu významu, takmer nebola šlachtená. V súčasnom období nie je na Slovensku registrovaná autochtónna odroda pšenice dvojzrnky. Opätovné zavedenie jej pestovania bude vyžadovat' dostupnost' odrôd adaptovaných na klimatické podmienky stanovišta, s požadovanými agronomickými a kvalitatívnymi parametrami, ktoré môžu prispiet’ k zvýšeniu diverzity, rozmanitejšej produkcii potravín a rozvoju miestnych trhov.

\section{Materiál a metódy}

Maloparcelové polné pokusy boli založené na Experimentálnej báze Fakulty agrobiológie a potravinových zdrojov SPU v Nitre Dolná Malanta, v západnej časti Žitavskej pahorkatiny. Územie je charakteristické kontinentálnou klímou, patrí do teplého agroklimatického regiónu s prevažne miernou zimou, dlhodobým úhrnom zrážok (1961 - 1990) 532,5 mm, dlhodobou priemernou teplotou vzduchu $9,8{ }^{\circ} \mathrm{C}$, za vegetačné obdobie $16,4{ }^{\circ} \mathrm{C}$, s nadmorskou výškou od $177 \mathrm{~m} \mathrm{n}$. $\mathrm{m}$. do 180 m n. m. (Špánik a Šiška, 1996). Hlavnou pôdnou jednotkou je hnedozem pseudoglejová vyvinutá na sprašových a polygénnych hlinách. Pôda je stredne t’ažká, hlinitá (Hanes, 1995).

Pokus bol založený blokovou metódou s náhodným usporiadaním v rámci osevného sledu hrach pšenica dvojzrnová - jačmeň jarný, v podmienkach ekologického hospodárenia. Vel'kost' jedného opakovania bola $10 \mathrm{~m}^{2}$ (8 riadkov, dížka $10 \mathrm{~m}$, medziriadková vzdialenost’ 0,125 m). Základné obrábanie pôdy pozostávalo z orby do híbky $0,20 \mathrm{~m}$, zaburinenost' počas vegetácie bola regulovaná mechanicky. Výsevok nevylúpaného zrna bol $170 \mathrm{~kg} / \mathrm{ha}$. V experimente boli hodnotené štyri odrody Triticum dicoccon (Schrank) pôvodom z Talianska a Rakúska.

V pokuse boli analyzované agronomické ukazovatele, nepriame ukazovatele mlynárskej kvality pomocou preosievacích sít typ AS200 (Retsch, Nemecko), nepriame ukazovatele pekárskej kvality: obsah mokrého lepku, gluten index podla AACC 38-12 pomocou Glutomatic 2200 (Perten Inst., Švédsko), pádové číslo pomocou Falling number 1100 (Perten Inst., Švédsko) podla AACC 56-81B; sedimentačná hodnota (Zeleny test) pomocou Shaker - Type SDZT4 podla ICC 116/1 (Santec, Slovensko). Reologické vlastnosti boli stanovené pomocou Brabender Farinografu - AT, typ 810151.

Fytoprotektívne kvalitatívne ukazovatele: viazané a vol'né fenoly boli stanovené podla Verma et al. (2009) a Van Hung et al. (2009) pomocou UV-VIS-1800 (Szimadzu), karotenoidy podla modifikovanej metódy Herrero-Barbudo et al. (2005) a Ligor and Buszewski (2012) pomocou HPLC s Aligent 6410 hmotnostným spektrometrom.

Získané experimentálne údaje za štyri vegetačné obdobia 2012 - 2015 boli vyhodnotené korelačnou analýzou, korelácie sú signifikantné, ak korelačný koeficient je signifikantný na hladine $p<0,01$. Na štatistickú analýzu bol využitý program STATISTICA verzia 10.0. 


\section{Výsledky a diskusia}

Korelačná analýza medzi agronomickými, nepriamymi mlynárskymi, pekárskymi a fytoprotektívnymi parametrami pšenice dvojzrnovej je významná z hladiska šlachtenia genotypov pre prípravu funkčných potravín, avšak tieto vzt’ahy zostávajú do významnej miery neprebádané. Korelačné koeficienty a ich preukaznost' vyjadrujú Tabul'ka 1 a Tabul'ka 2. Ak $r= \pm 0,33$ až $\pm 0,66$ medzi príslušnými znakmi je stredne silná (kladná alebo záporná) korelácia, ak $r= \pm 0,66$ až $\pm 0,99$, medzi znakmi je silná korelácia. Z korelačnej analýzy agronomických a kvalitatívnych ukazovatelov sa zistila stredne silná avšak negatívna korelácia medzi dlžkou stebla a obsahom hrubého proteínu, väznostou múky ako aj frakciou zrna menšou ako 2,2 mm (Tabul'ka 1). Priaznivejšie uvedené kvalitatívne parametre je možné dosiahnut pri odrodách s kratším steblom.

Koeficient produktívnych kláskov, vypočítaný ako podiel počtu fertilných kláskov k celkovému počtu kláskov v klase kladne koreloval (silná závislost') s reologickými parametrami, Zeleny testom, stredne silná kladná korelácia sa zistila s obsahom hrubého proteínu. Silná kladná korelácia medzi HTZ a zberovým indexom, ako aj medzi úrodou zrna s HTZ a zberovým indexom poukazuje na význam HTZ ako úrodotvorného prvku na formovaní úrody pšenice dvojzrnovej. Z hodnotených agronomických ukazovatelov je koeficient produktívnych kláskov významným parametrom pre predikciu pekárenskej kvality a HTZ, zberový index a dĺžka stebla významné pre výber odrôd s vyššou úrodnost’ou. Plevnaté druhy pšeníc sú charakteristické vyšším obsahom proteínu v porovnaní so pšenicou letnou, avšak údaje publikované vo vedeckej literatúre významne kolíšu v rozpätí od 11,2% do 19,05 \% (Hammed and Simsek 2014).

Medzi obsahom hrubého proteínu (HP) sa zistila signifikantná, stredne silná až silná kladná korelácia s nasledovnými parametrami pekárskej kvality: mokrý lepok, Zeleny test, pádové číslo, väznost̉ múky (Tabul'ka 2). Silná negatívna korelácia medzi hrubým proteínom a gluten indexom indikuje, že vyšší obsah hrubého proteínu bude viest' k jeho horšej pekárskej kvalite.

Silná kladná korelácia medzi HP a podielom frakcie zrna 2,2 - 2,5 mm môže potvrdzovat’ predpoklad, že vyšší obsah proteínu plevnatých druhov pšeníc je výsledkom vyššieho podielu povrchových vrstiev zrna, ktoré sú bohaté na proteíny a minerálne látky, k celkovému objemu zrna (Brandolini et al., 2008).

Zistená negatívna slabá korelácia medzi HP a frakciami zrna $>2,5 \mathrm{~mm}$ a $>2,8 \mathrm{~mm}$, potvrdzuje tento predpoklad aj v prípade pšenice dvojzrnovej. Silná negatívna korelácia medzi gluten indexom a vel'kostnou frakciou zrna 2,2 - 2,5 mm naznačuje, že negatívna korelácia medzi HP a gluten indexom je aj výsledkom tohto uvedeného vzt’ahu.

Stredne silná až silná kladná korelácia medzi Zeleny testom a väznost’ou múky, vývinom cesta, číslom kvality indikuje, že Zeleny test bude vhodným parametrom pre výber odrôd s priaznivými pekárskymi vlastnostami.

Z hodnotených parametrov fytoprotektívnej kvality zrna sa zistila stredne silná až silná kladná korelácia medzi obsahom $\beta$-karoténu a HP, väznostou múky, Zeleny testom, a podielom frakcie zrna 2,2-2,5 mm. Negatívna stredne silná korelácia bola zaznamenaná medzi gluten indexom.

Obsah luteínu, ako najvýznamnejšej zložky karotenoidov zo skupiny xantofylov, ktorý predstavuje 80 - 90 \% celkového obsahu karotenoidov v zrne, významne koreloval s obsahom $\beta$-karoténu, zeaxantínu, vol'ných aj viazaných fenolov. Zatial' čo $\beta$-karotén bol významnejšie viazaný na menšiu vel'kostnú frakciu zrna (od 2,2 do 2,5 mm), zeaxantín koreloval s frakciou zrna väčšou ako 2,5 a 2,8 mm. 


\begin{tabular}{|c|c|c|c|c|c|c|c|c|c|c|c|c|c|c|c|c|c|}
\hline Fenoly viazané & స్ & $\begin{array}{l}8 \\
\vdots \\
\\
\end{array}$ & $\underset{\widetilde{n}}{\tilde{\sigma}}$ & $\frac{a}{\sigma}$ & $\begin{array}{l}8 \\
0\end{array}$ & $\begin{array}{l}\stackrel{*}{*} \\
\stackrel{+}{0} \\
0\end{array}$ & 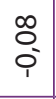 & $\begin{array}{l}\hat{n} \\
\text { o }\end{array}$ & $\frac{n}{\frac{n}{0}}$ & $\begin{array}{c}\stackrel{0}{m} \\
\vdots \\
o\end{array}$ & $\begin{array}{l}\stackrel{*}{*} \\
\stackrel{*}{n} \\
\vdots \\
0\end{array}$ & $\begin{array}{l}* \\
* \\
o \\
\vdots \\
\vdots\end{array}$ & 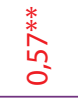 & 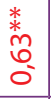 & $\begin{array}{l}\text { ** } \\
\text { in } \\
\stackrel{n}{n} \\
0\end{array}$ & $\begin{array}{l}\infty \\
0 \\
0\end{array}$ & $\begin{array}{l}* \\
* \\
0 \\
0 \\
0\end{array}$ \\
\hline Fenoly vol'né & 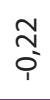 & $\underset{\check{N}}{\stackrel{ \pm}{0}}$ & 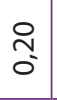 & ָั & 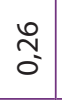 & 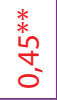 & s̊ & $\begin{array}{l}\tilde{n} \\
\stackrel{1}{1}\end{array}$ & $\begin{array}{l}n \\
\stackrel{0}{0} \\
0\end{array}$ & \begin{tabular}{l} 
* \\
\multirow{2}{m}{} \\
o. \\
0
\end{tabular} & $\begin{array}{l}\text { 絭 } \\
\text { 守 } \\
\text { 。 }\end{array}$ & $\begin{array}{l}\stackrel{*}{*} \\
\stackrel{*}{m} \\
\text { ó }\end{array}$ & $\begin{array}{l}\text { 娄 } \\
\text { م⿱ } \\
0\end{array}$ & $\begin{array}{l}\text { 光 } \\
\text { مٌ } \\
\stackrel{0}{0}\end{array}$ & $\begin{array}{l}\text { w } \\
\text { o } \\
m \\
0^{\prime}\end{array}$ & 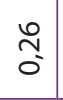 & $\stackrel{\circ}{\circ}$ \\
\hline$\beta$-karotén celozrn & \begin{tabular}{l} 
* \\
\multirow{2}{*}{} \\
0 \\
0 \\
0
\end{tabular} & 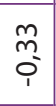 & 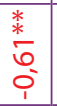 & 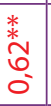 & $\begin{array}{l}\text { 类 } \\
\stackrel{0}{0}\end{array}$ & $\begin{array}{c}0 \\
m \\
o\end{array}$ & 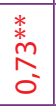 & $\stackrel{\circ}{m}$ & \begin{tabular}{l} 
* \\
\multirow{2}{*}{} \\
0 \\
0 \\
1
\end{tabular} & $\begin{array}{l}\text { 粪 } \\
\text { in } \\
\text { on } \\
0\end{array}$ & స̃ & $\begin{array}{l}\stackrel{n}{n} \\
\stackrel{0}{i}\end{array}$ & $\frac{N}{i}$ & $\begin{array}{l}\text { 糔 } \\
\stackrel{2}{0} \\
0\end{array}$ & $\underset{N}{N}$ & $\stackrel{8}{\circ}$ & \\
\hline Zeaxantín celozrn & 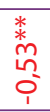 & 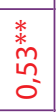 & $\frac{1}{\sigma}$ & $\frac{0}{1}$ & 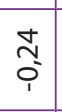 & $\frac{N}{1}$ & $\bar{N}$ & $\begin{array}{l}\infty \\
0 \\
0\end{array}$ & 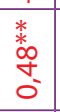 & $\begin{array}{l}\infty \\
0 \\
0 \\
1\end{array}$ & 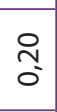 & 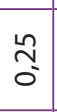 & $\stackrel{\stackrel{n}{N}}{0}$ & \begin{tabular}{l} 
* \\
ơ \\
\multirow{\circ}{0}{}
\end{tabular} & $\stackrel{-}{\circ}$ & & \\
\hline Luteín celozrn & ò & $\begin{array}{l}\infty \\
\stackrel{0}{0} \\
0\end{array}$ & \begin{tabular}{c}
\multirow{N}{N}{} \\
$\vdots$ \\
\end{tabular} & \begin{tabular}{l}
$*$ \\
\multirow{2}{*}{} \\
0 \\
0
\end{tabular} & $\begin{array}{l}\text { w } \\
\infty_{0} \\
\text { o } \\
0\end{array}$ & $\stackrel{\substack{m \\
0}}{0}$ & $\begin{array}{l}\text { * } \\
\stackrel{\infty}{m} \\
\text { m } \\
0\end{array}$ & $\stackrel{n}{0}$ & $\begin{array}{l}\tilde{N} \\
\stackrel{i}{1}\end{array}$ & $\begin{array}{c}\underset{*}{*} \\
\stackrel{\infty}{m} \\
0_{0}^{\prime}\end{array}$ & $\frac{0}{0}$ & ס & $\frac{9}{\sigma}$ & $\stackrel{8}{-}$ & & & \\
\hline $\begin{array}{l}\text { Úroda (86\% } \\
\text { sušina) }\end{array}$ & $\begin{array}{c}m \\
m \\
i \\
i\end{array}$ & $\begin{array}{l}\infty \\
0 \\
0\end{array}$ & $\begin{array}{l}0 \\
\text { m. } \\
0\end{array}$ & $\frac{n}{5}$ & $\begin{array}{l}\infty \\
0 \\
0\end{array}$ & $\begin{array}{l}\text { w } \\
\text { N } \\
\stackrel{n}{0} \\
o\end{array}$ & $\frac{0}{i}$ & 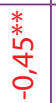 & $\underset{m}{m}$ & $\begin{array}{c}\tilde{m} \\
\vdots \\
0\end{array}$ & $\frac{\underset{*}{*}}{\stackrel{\infty}{\circ}}$ & $\begin{array}{l}\text { * } \\
\text { O̊ } \\
\text { ○' } \\
0\end{array}$ & $\stackrel{8}{\circ}$ & & & & \\
\hline Zberový index & \begin{tabular}{l} 
* \\
\multirow{2}{*}{} \\
$\hat{n}$ \\
$\underline{1}$ \\
$\underline{1}$
\end{tabular} & $\frac{1}{\sigma}$ & 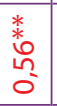 & $\begin{array}{l}\text { Ñ } \\
\text { i }\end{array}$ & $\begin{array}{c}\stackrel{\infty}{N} \\
\stackrel{1}{i}\end{array}$ & $\bar{ָ}$ & 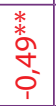 & 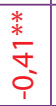 & \begin{tabular}{l} 
* \\
O \\
\multirow{0}{0}{}
\end{tabular} & $\begin{array}{l}\hat{0} \\
0\end{array}$ & $\begin{array}{l}\frac{*}{*} \\
\vdots \\
0 \\
0\end{array}$ & $\stackrel{8}{-}$ & & & & & \\
\hline HTZ ( $86 \%$ sušina) & $\begin{array}{l}\text { 䊑 } \\
\text { 守 } \\
0\end{array}$ & $\frac{1}{\sigma}$ & $\begin{array}{l}\stackrel{*}{*} \\
\text { in } \\
\text { م⿱ }\end{array}$ & $\frac{\sigma}{\bar{c}}$ & స̃ & $\stackrel{m}{m}$ & $\begin{array}{l}\text { 类 } \\
\text { 古 } \\
0\end{array}$ & $\begin{array}{l}\stackrel{*}{*} \\
\stackrel{2}{\Re} \\
\stackrel{n}{0}\end{array}$ & $\begin{array}{l}0 \\
m \\
o\end{array}$ & $\frac{\cong}{0}$ & $\underset{-}{\stackrel{-}{-}}$ & & & & & & \\
\hline Koef. prod. kláskov & $\underset{n}{n}$ & 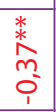 & $\begin{array}{c}\hat{m} \\
\tilde{o}_{1} \\
1\end{array}$ & $\begin{array}{l}\stackrel{*}{*} \\
\stackrel{*}{\circ} \\
\text { 。 }\end{array}$ & 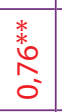 & $\begin{array}{l}\text { 粶 } \\
\text { 。 }\end{array}$ & $\begin{array}{l}\text { 絭 } \\
\hat{n} \\
0 \\
0\end{array}$ & $\stackrel{\infty}{\circ}$ & $\begin{array}{l}\text { 粰 } \\
\text { 品 } \\
\text { i }\end{array}$ & $\stackrel{-}{\circ}$ & & & & & & & \\
\hline DÍžka stebla & 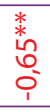 & $\stackrel{+}{m}$ & 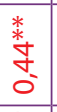 & $\begin{array}{l}\text { w } \\
\text { o } \\
m \\
\text { o } \\
\end{array}$ & $\begin{array}{l}\text { 粰 } \\
\text { nn } \\
\text { in } \\
\end{array}$ & $\begin{array}{c}\infty \\
\stackrel{1}{1} \\
i\end{array}$ & \begin{tabular}{l} 
* \\
\multirow{2}{*}{} \\
0 \\
0 \\
\\
1
\end{tabular} & $\frac{\infty}{i}$ & $\stackrel{8}{\circ}$ & & & & & & & & \\
\hline Obsah popola & $\stackrel{\stackrel{n}{n}}{\sigma}$ & $\begin{array}{l}8 \\
0 \\
\end{array}$ & 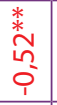 & $\tilde{\pi}$ & 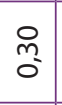 & $\frac{0}{i}$ & 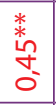 & $\stackrel{8}{\circ}$ & & & & & & & & & \\
\hline Hrubý proteín & \begin{tabular}{l}
$*$ \\
\multirow{2}{*}{} \\
○。 \\
0
\end{tabular} & $\begin{array}{l}\stackrel{0}{m} \\
\text { ó } \\
i\end{array}$ & 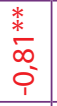 & $\begin{array}{l}\text { 类 } \\
\stackrel{2}{0} \\
\text { 。 }\end{array}$ & $\begin{array}{l}\text { 类 } \\
\infty \\
0 \\
0\end{array}$ & \begin{tabular}{l}
$\underset{*}{*}$ \\
\multirow{+}{*}{} \\
0
\end{tabular} & $\stackrel{8}{\circ}$ & & & & & & & & & & \\
\hline Číslo kvality & $\bar{\sigma}$ & ঙ্. & $\underset{N}{\tilde{N}}$ & $\begin{array}{l}\text { * } \\
\text { o } \\
0 \\
0 \\
0\end{array}$ & $\begin{array}{l}\text { 䊑 } \\
6 \\
0 \\
0\end{array}$ & $\stackrel{8}{-}$ & & & & & & & & & & & \\
\hline Väznost' múky & $\begin{array}{l}\text { * } \\
\text { 今 } \\
\text { ஸุ } \\
0\end{array}$ & 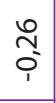 & 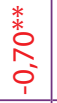 & $\begin{array}{l}\text { *ै } \\
\text { مै } \\
\text { ○े }\end{array}$ & $\stackrel{8}{-}$ & & & & & & & & & & & & \\
\hline Zeleny test & $\begin{array}{l}\text { * } \\
\text { 市 } \\
\text { 。 }\end{array}$ & 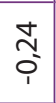 & 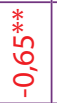 & $\underset{-}{\stackrel{0}{2}}$ & & & & & & & & & & & & & \\
\hline Glutén index & $\begin{array}{l}* \\
* \\
0 \\
0 \\
0 \\
0 \\
1\end{array}$ & $\frac{1}{\sigma}$ & $\stackrel{8}{-}$ & & & & & & & & & & & & & & \\
\hline$>2,8+>2,5 \mathrm{~mm}$ & $\begin{array}{l}* \\
* \\
\infty \\
10 \\
0 \\
0 \\
1\end{array}$ & $\stackrel{8}{-}$ & & & & & & & & & & & & & & & \\
\hline & $\begin{array}{l}\varepsilon \\
\Sigma \\
\text { ñ } \\
\text { N } \\
1 \\
\text { N } \\
\text { N }\end{array}$ & 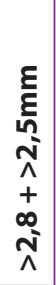 & 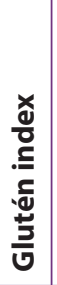 & 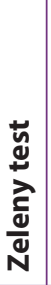 & 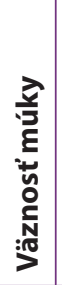 & 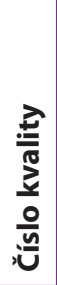 & $\begin{array}{l}\frac{5}{y} \\
0 \\
\frac{0}{2} \\
\frac{0}{2} \\
\frac{2}{2}\end{array}$ & 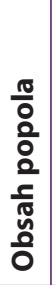 & 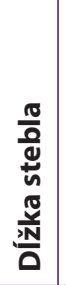 & 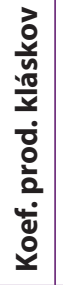 & 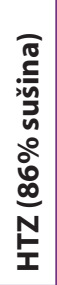 & 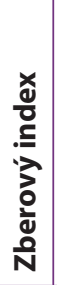 & 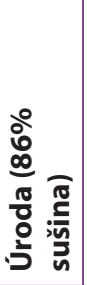 & 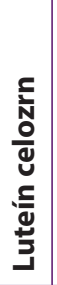 & 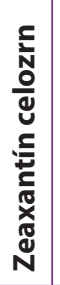 & 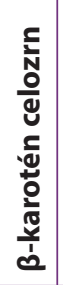 & 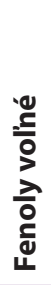 \\
\hline
\end{tabular}




\begin{tabular}{|c|c|c|c|c|c|c|c|c|c|c|c|c|c|c|c|c|c|c|}
\hline Fenoly viazané & $\begin{array}{l}\text { స్} \\
\text { i }\end{array}$ & 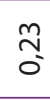 & $\begin{array}{l}8 \\
0 \\
\end{array}$ & $\frac{0}{\text { i }}$ & $\overline{\check{\sigma}}$ & $\frac{a}{0}$ & $\frac{1}{i}$ & ¿̊ & $\begin{array}{l}\text { * } \\
\stackrel{\infty}{m} \\
\text { o } \\
\end{array}$ & $\begin{array}{l}\stackrel{*}{*} \\
\stackrel{+}{*} \\
0\end{array}$ & $\begin{array}{l}* \\
* \\
\infty \\
\text { m } \\
0 \\
i\end{array}$ & $\begin{array}{l}\stackrel{*}{*} \\
\stackrel{*}{\leftarrow} \\
0\end{array}$ & $\begin{array}{l}\text { * } \\
\text { 衣 } \\
\text { m } \\
\text { i }\end{array}$ & $\begin{array}{l}\infty \\
0 \\
0 \\
i\end{array}$ & $\begin{array}{l}\underset{*}{*} \\
\stackrel{*}{0} \\
\stackrel{0}{0}\end{array}$ & $\begin{array}{l}\text { * } \\
\text { N } \\
\text { ஸn } \\
0\end{array}$ & $\begin{array}{l}\stackrel{0}{\circ} \\
\text { O }\end{array}$ & $\begin{array}{l}\text { * } \\
\text { o } \\
6 \\
0 \\
0\end{array}$ \\
\hline Fenoly vol'né & 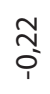 & $\frac{\hat{o}}{i}$ & 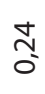 & $\frac{0}{0}$ & 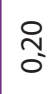 & $\stackrel{\text { సે }}{0}$ & $\frac{\Delta}{i}$ & 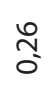 & \begin{tabular}{l}
$\underset{*}{*}$ \\
$\stackrel{*}{+}$ \\
\multirow{0}{*}{}
\end{tabular} & $\begin{array}{l}\underset{*}{*} \\
\stackrel{*}{+} \\
\stackrel{0}{0}\end{array}$ & 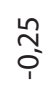 & 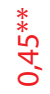 & 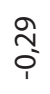 & ô & $\begin{array}{l}\text { * } \\
\text { م } \\
0 \\
0\end{array}$ & $\begin{array}{l}\text { * } \\
\text { o } \\
\text { ñ } \\
0\end{array}$ & $\begin{array}{l}\stackrel{0}{N} \\
\text { - }\end{array}$ & $\stackrel{8}{-}$ \\
\hline$\beta$-karotén & \begin{tabular}{l}
$*$ \\
\multirow{2}{*}{} \\
$\stackrel{0}{0}$ \\
0 \\
0
\end{tabular} & $\begin{array}{l}\text { no } \\
0 \\
0\end{array}$ & $\begin{array}{l}\stackrel{m}{m} \\
\text { o }\end{array}$ & 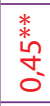 & $\begin{array}{l}* \\
* \\
6 \\
0 \\
0 \\
1\end{array}$ & \begin{tabular}{l}
$*$ \\
\multirow{2}{*}{} \\
$\stackrel{\sigma}{0}$ \\
\end{tabular} & 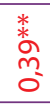 & $\begin{array}{l}\text { * } \\
\stackrel{*}{*} \\
\vdots\end{array}$ & $\begin{array}{l}\text { 絭 } \\
\text { m } \\
\text { o }\end{array}$ & $\frac{a}{0}$ & $\frac{\infty}{\sigma^{\prime}}$ & $\begin{array}{l}\stackrel{0}{n} \\
\text { o. }\end{array}$ & ò & $\begin{array}{l}\underset{*}{*} \\
\stackrel{*}{0} \\
0\end{array}$ & $\begin{array}{l}\text { * } \\
\text { 苋 } \\
0 \\
0\end{array}$ & 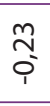 & $\stackrel{8}{-}$ & \\
\hline Zeaxantín & \begin{tabular}{l} 
* \\
\multirow{2}{*}{} \\
$\hat{n}$ \\
0 \\
0 \\
1
\end{tabular} & $\begin{array}{c}\text { m } \\
\text { ị }\end{array}$ & $\begin{array}{l}\text { * } \\
\stackrel{n}{n} \\
0 \\
0\end{array}$ & $\frac{0}{0}$ & $\frac{N}{\sigma}$ & $\frac{0}{0}$ & $\frac{N}{0}$ & 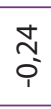 & $\frac{N}{i}$ & $\begin{array}{l}\text { L } \\
\text { O } \\
0\end{array}$ & $\stackrel{\text { L }}{\circ}$ & $\frac{N}{i}$ & ò & $\begin{array}{c}\bar{N} \\
\stackrel{1}{1}\end{array}$ & \begin{tabular}{l} 
* \\
\multirow{6}{\circ}{} \\
0 \\
0
\end{tabular} & $\stackrel{8}{\circ}$ & & \\
\hline Luteín & ò & $\frac{\text { in }}{\mathbf{i}}$ & $\stackrel{\circ}{\circ}$ & 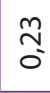 & \begin{tabular}{l}
\multirow{N}{*}{} \\
D
\end{tabular} & $\bar{\sigma}_{0}$ & $\frac{\infty}{\sigma}$ & $\begin{array}{l}\text { * } \\
\stackrel{\infty}{m} \\
\text { o }\end{array}$ & $\stackrel{\text { p. }}{\text { ó }}$ & 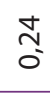 & $\bar{o}$ & 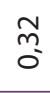 & $\begin{array}{l}\text { Lo } \\
\text { o }\end{array}$ & $\begin{array}{l}\text { * } \\
\text { o } \\
m \\
0 \\
0\end{array}$ & $\stackrel{8}{-}$ & & & \\
\hline Hrubý protein & $\begin{array}{l}\text { * } \\
\text { ○ू } \\
0 \\
0\end{array}$ & $\begin{array}{l}n \\
0 \\
0 \\
0\end{array}$ & $\begin{array}{l}\text { } \\
\text { p} \\
\text { i }\end{array}$ & 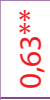 & $\begin{array}{l}\text { * } \\
\text { * } \\
\infty \\
0 \\
0 \\
\end{array}$ & 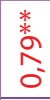 & $\begin{array}{l}\text { * } \\
\stackrel{*}{\circ} \\
0 \\
\end{array}$ & 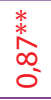 & \begin{tabular}{l}
$*$ \\
\multirow{2}{*}{} \\
$\delta$ \\
\end{tabular} & $\frac{\infty}{\sigma}$ & $\underset{\check{J}}{\stackrel{\Xi}{N}}$ & \begin{tabular}{l}
$*$ \\
\multirow{*}{*}{} \\
\multirow{\sigma}{*}{}
\end{tabular} & $\frac{\nabla}{\circ}$ & $\stackrel{8}{-}$ & & & & \\
\hline MTI & $\underset{\sigma}{\stackrel{\Xi}{\sigma}}$ & 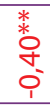 & $\underset{\delta}{\approx}$ & $\begin{array}{l}\infty \\
\stackrel{\infty}{N} \\
\text { i }\end{array}$ & 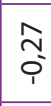 & $\frac{0}{0}$ & $\begin{array}{l}\text { ᄋ } \\
\text { ○ }\end{array}$ & $\begin{array}{l}\text { no } \\
\text { o } \\
\text { i }\end{array}$ & $\begin{array}{l}\text { * } \\
\text { wn } \\
\text { nn } \\
\text { o } \\
\end{array}$ & $\begin{array}{l}* \\
* \\
0 \\
0 \\
0 \\
0\end{array}$ & $\begin{array}{l}* \\
* \\
0 \\
0 \\
0\end{array}$ & \begin{tabular}{l} 
* \\
\multirow{2}{*}{} \\
0 \\
0 \\
0 \\
\end{tabular} & $\stackrel{8}{-}$ & & & & & \\
\hline Číslo kvality & $\bar{\sigma}$ & $\frac{\infty}{\sigma}$ & $\begin{array}{l}\text { ָે } \\
\text { i }\end{array}$ & $\begin{array}{l}\text { * } \\
\text { 告 } \\
\text { o }\end{array}$ & 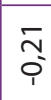 & $\begin{array}{l}* \\
* \\
0 \\
0 \\
0 \\
0\end{array}$ & $\frac{\nabla}{\sigma}$ & \begin{tabular}{l}
$\underset{*}{*}$ \\
\multirow{0}{*}{} \\
$\stackrel{0}{0}$
\end{tabular} & $\begin{array}{l}\stackrel{*}{*}^{*} \\
\alpha \\
\sigma\end{array}$ & $\begin{array}{l}\text { 蒾 } \\
\stackrel{2}{\alpha} \\
0\end{array}$ & \begin{tabular}{l} 
* \\
\multirow{6}{*}{} \\
0 \\
0
\end{tabular} & $\stackrel{8}{-}$ & & & & & & \\
\hline Doba mäknutia & 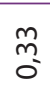 & $\begin{array}{l}\text { * } \\
\text { م } \\
\text { m } \\
\text { o }\end{array}$ & $\frac{1}{\sigma}$ & $\frac{a}{\bar{c}}$ & $\begin{array}{l}\stackrel{0}{n} \\
\text { p}\end{array}$ & O & $\frac{0}{0}$ & o: & $\begin{array}{l}* \\
* \\
\infty \\
+ \\
+ \\
\\
1\end{array}$ & $\begin{array}{l}\stackrel{*}{*} \\
\stackrel{*}{*} \\
\text { ó }\end{array}$ & $\stackrel{\text { O }}{-}$ & & & & & & & \\
\hline Stabilita cesta & $\begin{array}{l}\text { ò } \\
\text { i }\end{array}$ & 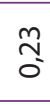 & $\frac{n}{i}$ & 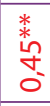 & $\begin{array}{l}\text { no } \\
\text { o }\end{array}$ & 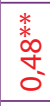 & ס̊ & \begin{tabular}{l} 
* \\
\multirow{\Xi}{*}{} \\
\end{tabular} & $\begin{array}{l}* \\
* \\
\infty \\
0 \\
0 \\
\end{array}$ & $\stackrel{\text { \& }}{-}$ & & & & & & & & \\
\hline Vývin cesta & $\frac{\ln }{0}$ & $\frac{\ln }{0}$ & $\begin{array}{l}\text { ָิ } \\
\text { i }\end{array}$ & \begin{tabular}{l}
${ }^{*}$ \\
\multirow{2}{*}{} \\
0 \\
0
\end{tabular} & $\begin{array}{l}\text { N } \\
\text { O̦ }\end{array}$ & \begin{tabular}{l} 
* \\
\multirow{6}{*}{} \\
0 \\
0
\end{tabular} & $\frac{0}{\circ}$ & $\begin{array}{l}\text { * } \\
* \\
0 \\
0 \\
0 \\
0\end{array}$ & $\stackrel{8}{-}$ & & & & & & & & & \\
\hline Väznost' múky & 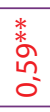 & $\begin{array}{l}m \\
0 \\
0 \\
0\end{array}$ & $\begin{array}{l}\text { શ్ } \\
\text { ָे }\end{array}$ & $\begin{array}{l}* \\
* \\
0 \\
0 \\
0 \\
0\end{array}$ & $\begin{array}{l}\text { * } \\
\stackrel{*}{\circ} \\
\text { م. } \\
\end{array}$ & $\begin{array}{l}\text { * } \\
\stackrel{2}{ } \\
\text { ○ } \\
\end{array}$ & 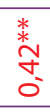 & $\stackrel{8}{\circ}$ & & & & & & & & & & \\
\hline Pádové číslo & 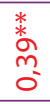 & $\begin{array}{l}8 \\
0 \\
\end{array}$ & $\frac{\sigma}{i}$ & 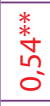 & \begin{tabular}{l} 
* \\
\multirow{2}{*}{} \\
\multirow{0}{*}{} \\
0
\end{tabular} & $\begin{array}{l}\text { * } \\
\text { * } \\
\text { O } \\
0 \\
\end{array}$ & $\stackrel{8}{-}$ & & & & & & & & & & & \\
\hline Zeleny test & $\begin{array}{l}\text { 水 } \\
\text { 守 } \\
\text { - }\end{array}$ & $\bar{o}$ & 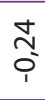 & $\begin{array}{l}\text { 䊑 } \\
\stackrel{0}{\circ} \\
\text { ó }\end{array}$ & \begin{tabular}{l} 
** \\
\multirow{2}{*}{} \\
0 \\
0 \\
0
\end{tabular} & $\underset{-}{\stackrel{8}{-}}$ & & & & & & & & & & & & \\
\hline Gluten index & $\begin{array}{l}\text { * } \\
* \\
0 \\
0 \\
0 \\
\\
\end{array}$ & $\frac{\infty}{\sigma^{\prime}}$ & $\frac{1}{\sigma}$ & \begin{tabular}{|l|} 
* \\
足 \\
? \\
i \\
\end{tabular} & $\stackrel{8}{-}$ & & & & & & & & & & & & & \\
\hline Mokrý lepok & $\stackrel{\nwarrow}{\tilde{\sigma}}$ & $\frac{\infty}{i}$ & $\begin{array}{l}\widetilde{O} \\
0 \\
0\end{array}$ & $\underset{-}{8}$ & & & & & & & & & & & & & & \\
\hline$>2,8+>2,5 \mathrm{~mm}$ & $\begin{array}{l}* \\
* \\
0 \\
0 \\
0 \\
0 \\
\end{array}$ & $\begin{array}{l}* \\
* \\
\infty \\
\infty \\
0 \\
\\
\end{array}$ & $\stackrel{8}{-}$ & & & & & & & & & & & & & & & \\
\hline$<2,2 \mathrm{~mm}$ & $\frac{m}{0}$ & $\underset{-}{\stackrel{8}{-}}$ & & & & & & & & & & & & & & & & \\
\hline & 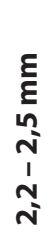 & $\begin{array}{l}\varepsilon \\
\varepsilon \\
\text { N } \\
\text { v }\end{array}$ & $\begin{array}{l}\varepsilon \\
\varepsilon \\
n \\
\hat{N} \\
\Lambda \\
+ \\
\infty \\
N \\
\Lambda\end{array}$ & $\begin{array}{l}\frac{y}{0} \\
\frac{0}{0} \\
\frac{1}{2} \\
\frac{y}{0} \\
\frac{0}{2}\end{array}$ & 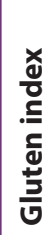 & 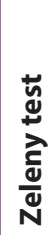 & 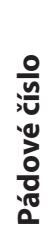 & 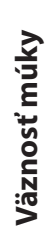 & 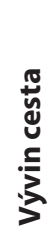 & 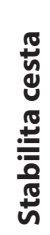 & 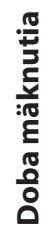 & 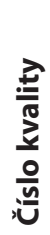 & $\bar{\Sigma}$ & 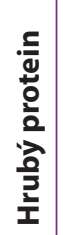 & $\frac{\subseteq}{\bar{J}}$ & 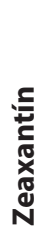 & 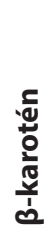 & 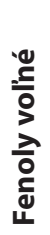 \\
\hline
\end{tabular}




\section{Závery}

Korelačná analýza kvantitatívnych a kvalitatívnych parametrov Triticum dicocco môže byt’ významná z hladiska šlachtenia odrôd vhodných na prípravu funkčných potravín. Významným kvalitatívnym parametrom je obsah hrubého proteínu, s preukaznou silnou koreláciou so Zeleny testom, obsahom mokrého lepku, väznostou múky, avšak aj obsahom $\beta$-karoténu. Silná negatívna korelácia hrubého proteínu a gluten indexu indikuje možné t’ažkosti pri výbere genotypov s vysokou pekárskou kvalitou. Obsah zeaxantínu a $\beta$-karoténu je v korelácii s vel'kostnými kategóriami zrna, $\beta$-karotén koreluje s menším zrnom, zeaxantín s väčším. Obsah luteínu, volných aj viazaných fenolov nie je v korelácii s vel'kostou zrna, medzi nimi navzájom je však stredne silná až silná kladná korelácia. Z kvantitatívnych ukazovatel'ov je koeficient produktívnych kláskov vhodným indikátorom pre predikciu pekárenskej kvality. HTZ, zberový index a dĺžka stebla sú významné pre výber odrôd s vyššou úrodnostou.

\section{Pod’akovanie}

Práca vznikla na základe výsledkov realizácie projektu ITEBIO „Podpora a inovácie technológií špeciálnych výrobkov a biopotravín pre zdravú výživu ludí", ITMS: 26220220115 v rámci operačného programu Výskum a vývoj, financovaného z Európskeho fondu regionálneho rozvoja.

\section{Literatúra}

Brandolini, A., Hidalgo, A., Moscartolo, S. 2008. Chemical composition and pasting properties of einkorn (Triticum monococcum L. subsp. monococcum) whole meal flour. J. Cereal Sci., no. 47, p. 599-609.

Feldman, M. 2001. The origin of cultivated wheat. In Bonjean, A.P., Angus, W.J. (eds) The world wheat books a history of wheat breeding. Paris: Lavoisier Publishing, p. 3-56. ISBN 978-1898298724.

Hajnalová, M., Dreslerová, D. 2010. Ethnobotany of einkorn and emmer in Romania and Slovakia: towards interpretation of archaeological evidence. Památky archeologické, vol. 101, p.169-202.

Hammed, A.M., Simsek, S. 2014. Hulled wheats: a review of nutritional properties and processing methods. Cereal Chemistry, vol. 91, p. 97-104.

Hanes, J. 1995. Atropogénne vplyvy na vlastnosti polnohospodárskych pôd. Nitra: VŠP, s. 89. ISBN 80-7137-238-2.

Herrero-Barbudo, M.C., Granado-Lorencio, F., Blanco-Navaro, I., Olmedilla-Alonso, B. 2005. Retinol, $\alpha$ - and $\gamma$-tocopherol and carotenoids in natural and vitamin A- and E-fortified dairy products commercialized in Spain. InternationI Dairy J., vol. 15, p. 521-526. https://doi.org/10.1016/j.idairyj.2004.07.011

Ligor, M., Buszewski, B. 2012. Effect of kale cultivation conditions on biosynthesis of xanthophylls. J. of Food Research, no. 1, p. 74-84. http://dx.doi.org/10.5539/jfr.v1n4p74

Špánik, F., Šiška, B. 1996. Biometeorológia. Nitra: VŠP, 168 s. ISBN 80-7137-259-5.

Van Hung, P., Maeda, T., Miyatake, K., A Morita, N. 2009. Total phenolic compounds and antioxidant capacity of wheat graded flours by polishing method. Food Reasearch International, no. 42, p. 185-190. https// doi.org/10.1016/j.foodres.2008.10.005

Verma, B., Hucl, P., Chibbar, R.N. 2009. Phenolic acid composition and antioxidant capacity of acid and alkali hydrolysed wheat bran fraction. Food Chemistry, no. 116, p. 947-954. https://doi.org/10.1016/j. foodchem.2009.03.060 